\title{
Translating Scientific Terms
}

\author{
Luu Hoang Mai \\ Thu Dau Mot University, Vietnam \\ Luu Thi Bich Ngoc \\ Open University, Ho Chi Minh City, Vietnam \\ Luu Trong Tuan \\ Open University, Ho Chi Minh City, Vietnam
}

\begin{abstract}
Translation theorists still have been on the quest for an approach to translation units in scientific term translation. The paper presents two principles of scientific term translation - "recombination of semantic components" and "functional equivalence" - which, in combination with Vinay \& Darbelnet's (1977) translation procedures, produce procedures of translating terms outside the context. The paper further proposes Coordinate Translation Model which helps decode apposite translation units for the translation of contextualized terms.
\end{abstract}

Index Terms - scientific term, recombination of semantic components, functional equivalence, Coordinate Translation Model

\section{INTRODUCTION}

From Newmark's (1995, p. 151) standpoint, the distinction between scientific translation and the other types of translation resides in scientific terms in the texts. The authors' aesthetic intention is the focus of literary translation whereas the precision of scientific terms contributes to scientific translation effectiveness. "Translating terms can be a challenge for translators once even certain bilingual dictionaries of a science fail to distinguish academic meaning of a term from its common meaning" (Luu, 2011). In Lam's (2003) bilingual medical dictionary (pp. 179, 236), for example, the terms "perspiration" và "sweating" are translated as "ra mồ hôi" ("releasing sweat") in Vietnamese language.

Although both terms refer to "the act or process of excreting fluid by the sudoriferous glands through pores in the skin" (Anderson et al., 2002, pp. 1323, 1664), "perspiration" implies a physiological process whereas "sweating" denotes the excretion of sweat caused by heavy workload, fear, illness, or medication. The semantic differences render "perspiration" academic in style and "sweating" academic in case of illness or medication and popular in case of heavy workload or trepidation. The English-Chinese medical dictionary has translated "perspiration" as "chuhan" and translated "sweating" as "fahan" (see Mengzhi, 1999). Likewise, in translating them into Vietnamese language, the semantic as well as stylistic distinction between "perspiration" and "sweating" should be taken into account as displayed in Table 1.

TABLE 1

TRANSLATING “PERSPIRATION” AND "SWEATING” INTO VIETNAMESE LANGUAGE

\begin{tabular}{|l|l|l|l|l|}
\hline Terms & Meanings & Scale of style & Physiological states & Vietnamese translations \\
\hline Perspiration & Natural excretion of sweat & Academic & Normal (neutral) & Tiết / bài tiết / ra mồ hôi \\
\hline Sweating & $\begin{array}{l}\text { Excretion of sweat caused by } \\
\text { illness or medication }\end{array}$ & Professional & $\begin{array}{l}\text { Abnormal } \\
\text { (negative) }\end{array}$ & Đố / vã mồ hôi \\
\cline { 2 - 5 } & $\begin{array}{l}\text { Excretion of sweat caused by } \\
\text { heavy workload or trepidation }\end{array}$ & Popular & $\begin{array}{l}\text { Abnormal } \\
\text { (negative) }\end{array}$ & Đố / vã / toát mồ hôi \\
\hline
\end{tabular}

From the significance of accurately translating terms in scientific texts via the above illustration, the aim of the paper entails exploring principles and procedures of translating scientific terms, thereby augmenting the quality of scientific translation.

\section{PRINCIPLES OF SCIENTIFIC TERM TRANSLATION}

The two principles guiding the translation of scientific terms include:

\section{A. Recombination of Semantic Components}

Bijective mapping in translating English terms into Vietnamese language does not always occur. English single words, complex words, and phrases may not be translated as Vietnamese single words, complex words, and phrases respectively. On the contrary, the recombination of the semantic components of the terms may occur in the target language. 
From Luu's (2011) view, "If the semantic components in the target language are tightly compacted, the translated terms will be single words, and if the semantic components in the target language are loosely compacted, the translated terms will be complex words or phrases". Figure 1 displays "recombination of semantic components" principle.

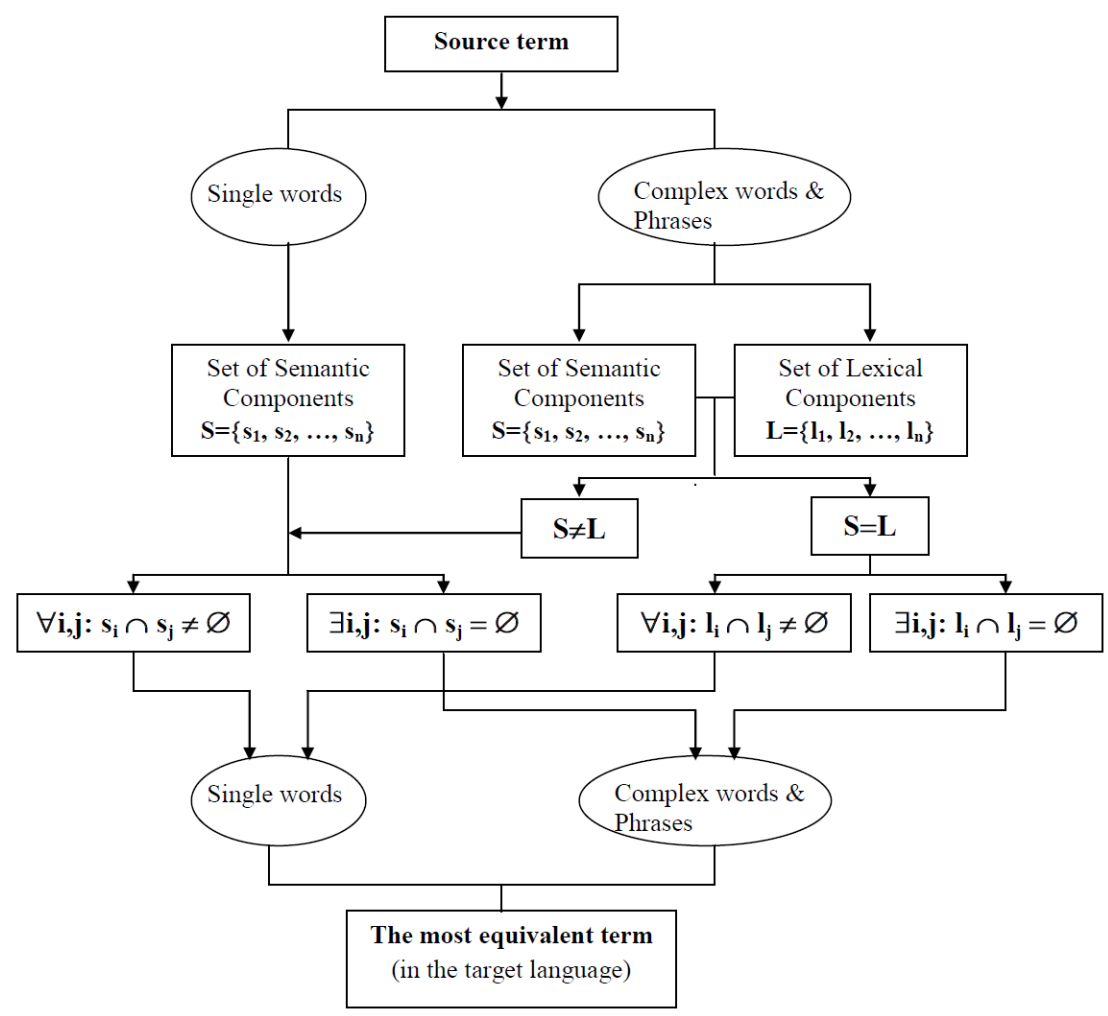

Figure 1. Recombination of semantic components in term translation

As Figure 1 reveals, "if a term is a single word, the translator will analyze its set of semantic components $\mathbf{S}=\left\{\mathbf{S}_{\mathbf{1}}\right.$, $\left.\mathbf{s}_{\mathbf{2}}, \ldots, \mathbf{s}_{\mathbf{n}}\right\}$ ( $\mathrm{S}=$ semantic component) (the set of semantic components is explored through its definition). In case its semantic components are tightly compacted, i.e. subsets of every semantic component are joint, or their intersection is not the empty set $\left(\forall \mathbf{i}, \mathbf{j}: \mathbf{s}_{\mathbf{i}} \cap \mathbf{S}_{\mathbf{j}} \neq \varnothing\right)$, term translation in the target language will be a single word" (Luu, 2011) as "lung" is rendered as "phổi" in Vietnamese.

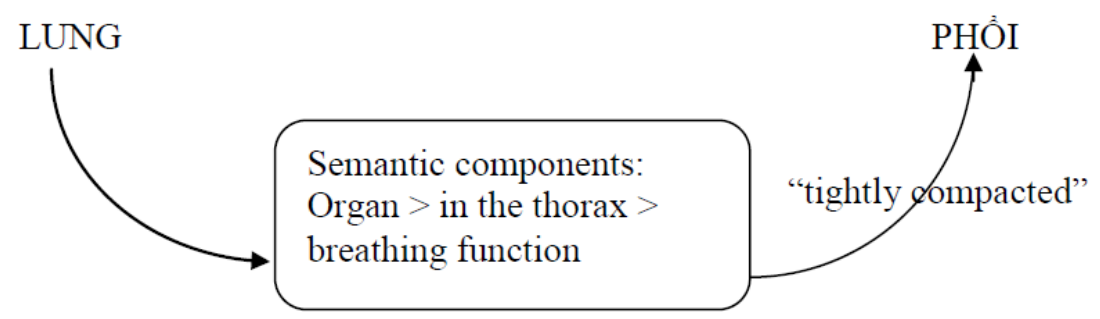

However, from Luu's (2011) perspective, "if the semantic components of a single word are not tightly joint, i.e. there exist at least two disjoint subsets of semantic components, or their intersection is the empty set $\left(\exists \mathbf{i}, \mathbf{j}: \mathbf{s}_{\mathbf{i}} \cap \mathbf{s}_{\mathbf{j}}=\varnothing\right)$ ", term translation in the target language will be a complex word or phrase as "malaria" is translated as "sốt rét" in Vietnamese language.

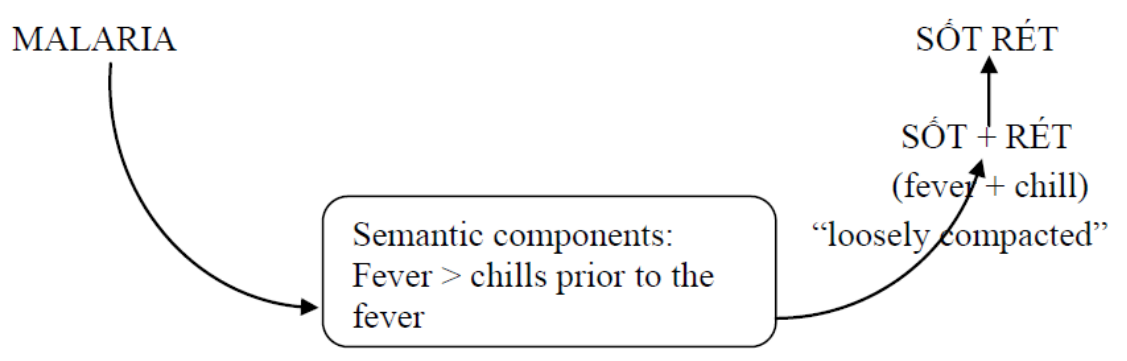


If the term is a complex word or phrase, its set of semantic components $\mathbf{S}=\left\{\mathbf{s}_{\mathbf{1}}, \mathbf{s}_{2}, \ldots, \mathbf{s}_{\mathbf{n}}\right\}$ ( $\mathrm{S}=$ semantic component) and its set of lexical components $\left(\mathbf{L}=\left\{\mathbf{l}_{\mathbf{1}}, \mathbf{l}_{\mathbf{2}}, \ldots, \mathbf{l}_{\mathbf{n}}\right\}\right)$ ( $\mathrm{L}=$ lexical component) has to be dissected. "If its set of lexical components does not reflect its set of semantic components $(\mathbf{S} \neq \mathbf{C})$, then its set of semantic components should be analyzed, like the case of the term as a single word" (Luu, 2011); for example, "smallpox" is rendered as "đậu mùa" in Vietnamese.

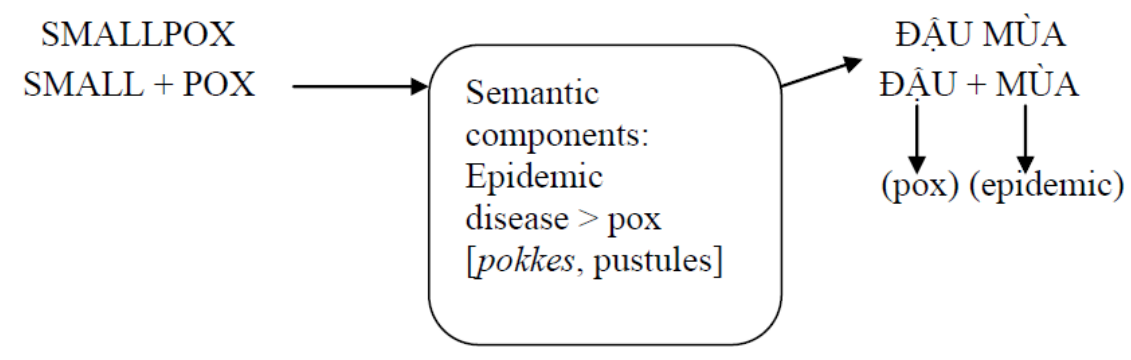

However, if the term's set of lexical components reflect its set of semantic components $(\mathbf{S}=\mathbf{L})$, its set of lexical components is then dissected. "If its lexical components are tightly compacted, i.e. subsets of every lexical component are joint or their intersection is not the empty set $\left(\forall \mathbf{i}, \mathbf{j}: \mathbf{l}_{\mathbf{i}} \cap \mathbf{l}_{\mathbf{j}} \neq \varnothing\right)$ )" (Luu, 2011), term translation in the target language will be a single word as "lipothymia" is translated as "xỉu" (fainting) and "white water lily" is translated as "súng" (a species of plant) in Vietnamese language.

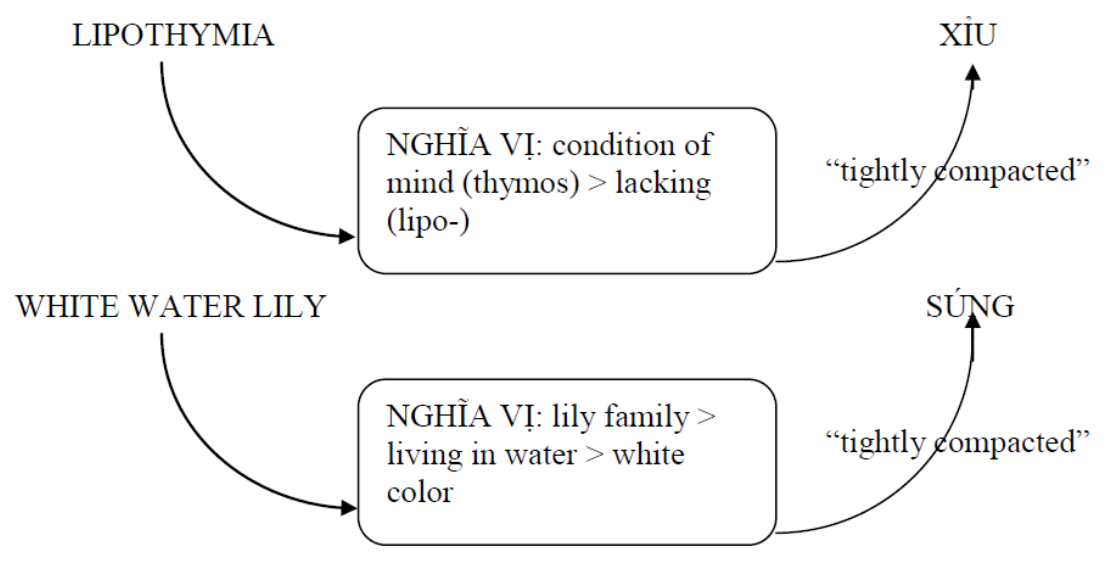

However, "if the lexical components of a complex word or phrase are not tightly joint, i.e. there exist at least two disjoint subsets of lexical components, or their intersection is the empty set $\left(\exists \mathbf{i}, \mathbf{j}: \mathbf{l}_{\mathbf{i}} \cap \mathbf{l}_{\mathbf{j}}=\varnothing\right)$ )" (Luu, 2011), term translation in the target language will be a complex word or phrase as "myasthenia" is translated as "bệnh nhược cơ" in Vietnamese language, a recombination of disjoint translated lexical components except the merger of "a" and "sthen" into the translation "nhược" (feeble).

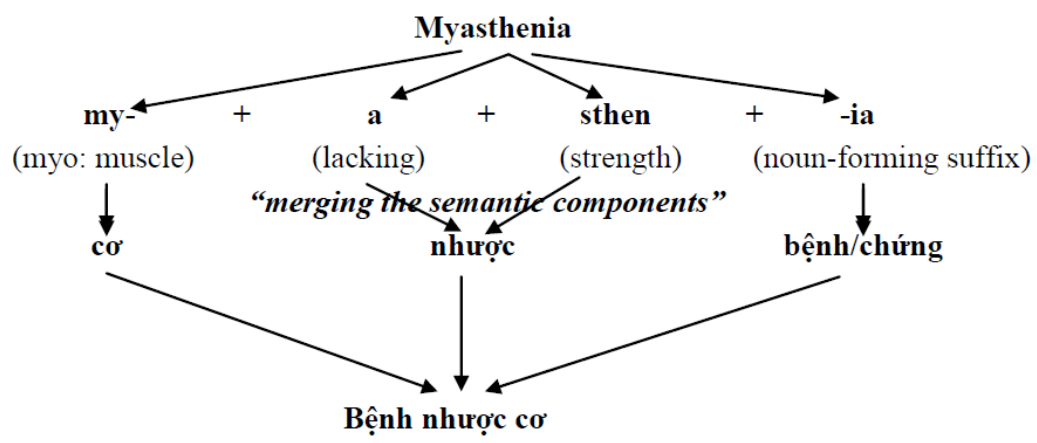

\section{B. Functional Equivalence Principle}

Translating a scientific term entails seeking functional equivalence "between the term in the source language and its translation in the target language" (Luu, 2011). Arntz \& Picht (1991, p. 160) suggest four levels of functional equivalence:

1) Complete conceptual equivalence 
An illustration for this level of functional equivalence is the case of "phagocyte" (phago-: eat; cyte: cell) to be translated as "thực bào" (thực: eat; bào: cell), and "hemolysis" (hemo-: blood; -lysis [Gk, lysein, to loose]: breaking down or decomposition) to be translated as "tán huyết" (tán: breaking down; huyết: blood).

2) Partial equivalence

Translating the term "hemoglobin" into Vietnamese language is an illustration for this level of functional equivalence. The overlapping between the term "hemoglobin" and its translation "huyết sắc tố" is the component "hemo-" meaning blood (huyêt: blood), whereas the other component of the term "globin" [L, globus] meaning "ball" is not analogous to the component "sắc tố" (pigment) of the translation.

Likewise, "smallpox" is rendered as "bệnh đậu mùa" in Vietnamese; however, their only overlapping is "pox" implying pustules, and the other component of the term "small" and that of its translation "mùa" are divergent, which produces partial equivalence between the term and its translation.

3) Inclusion, a term merges into another

The term "protein" is translated as "đạm" in Vietnamese language. Originally meaning "nitrogen gas", the SinoVietnamese term "đạm" has taken on the meaning "substances containing nitrogen", so is a hypernym including the hyponym "protein".

Similarly, the term "carbon dioxide" is translated as "thán khí" in Vietnamese language, which means "a gas being composed of carbon", so its translation "thán khí" is a hypernym embracing the hyponym "carbon dioxide".

On the contrary, the hypernym "problem" with high frequency in scientific terms does not have the equivalent hypernym in Vietnamese. Therefore, using the hyponyms of the term "problem", it can be translated as:

+ "hội chứng" (syndrome): breathing problems $\rightarrow$ hội chứng khó thở (syndrome of dyspnea)

+ "bất thường" (anomaly): Fallopian tube problems $\rightarrow$ bất thường ở ống dẫn trứng (anomaly in oviduct)

+ "rối loạn" (disorder): sleep problems $\rightarrow$ rối loạn giấc ngủ (disorder of sleep)

4) No conceptual equivalence

The term "epidemic parotitis" is literally translated as "viêm tuyến mang tai dịch tể"; however, its common translation "bệnh quai bị" (bag-shaped swollen jaw) is entirely unequivalent to the term.

Certain terms and their translated terms are unequivalent in terms of lexical roots. However, they will become complete equivalents in view of the term's definition. The term "potential energy" is translated as "thế năng" ([position],[energy]), whereas potential builds upon two Latin roots, potis or latent power, and posse, to be able, so the term and its translation seemingly reflect partial equivalence. However, the definition "Potential energy is the energy an object has because of its position in a gravitational field, magnetic field, or similar environment that affects the object" (Ebbing et al., 1995, p. 82) shows that the term and its Vietnamese translation "thế năng" are complete equivalents.

The last degree of functional equivalence, no conceptual equivalence, refers to the last resort suggested by Ohly (1987) that if no appropriate equivalent can be encountered or created in the target language, the foreign word should be retained after it has undergone certain adaptations to be more pronounceable and memorable. Ohly's last resort is a part of Jakobson's (1959, p. 234) acknowledgement on the use of "loanwords or loan-translations, neologisms or semantic shifts, and circumlocutions" in case of deficiency of equivalent terms in the target language.

For instance, the most common translation of the term "Parkinson's disease" is the loanword "Bệnh Parkinson". The term is also less commonly translated as "Bệnh liệt run", a loan translation from the term "paralysis agitans", which James Parkinson also employed to refer to this disease (see Le, 1984, p. 185). The term nystagmus, on the other hand, is transferred into Vietnamese language through the circumlocution "dấu hiệu rung giật nhãn cầu" (the sign of jerky movements of the eyes).

\section{TERm TRAnSLATION PROCEDURES}

Vinay \& Darbelnet's (1977) translation procedures encompass:

1) Direct borrowing

Illustrations of direct borrowing include "test" and "oxygen", which however should be translated as "xét nghiệm" and "dưỡng khí" respectively, rather than being retained in the target language.

2) Calque/loan translation

In calque or loan translation procedure, the lexical components of the term in the source language is translated, then arranged in the target language in a sequence analogous or nearly analogous to that of the lexical components of the term in the source language:

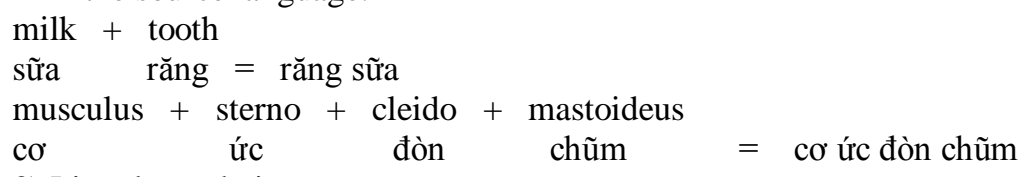

3) Literal translation

Literal translation occurs in case of the coincidence between the set of semantic components and the set of lexical components. For instance: 


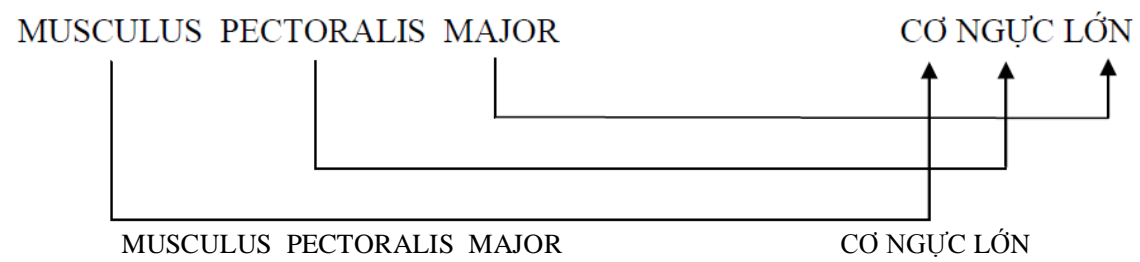

While loan translation entails the syntax of the components, literal translation entails the semantic relationship among the components. For example,

Loan translation:

Literal translation:

rheumatic + fever

thấp sốt = sốt thấp

drug + fever

thuốc sốt = sốt do thuốc (fever caused by drug)

The first components of both terms "rheumatic" (implying "rheumatic factor") and "drug" refer to the causes of the diseases. Literal translation elucidates the causal relationship in the translation of "drug fever", but loan translation does not refer to this sort of relationship, so the term is translated as "sốt thấp" instead of "sốt do yếu tố thấp" (fever caused by rheumatic factor).

4) Transposition

Transposition entails the grammatical changes but no semantic changes. The following examples denote changes in word formation from the source terms to their translations:
vein (single word)
arteriosclerosis (complex word)
translated
tĩnh mạch (complex word)
xơ cứng động mạch (phrase)
$\longrightarrow \quad$ xơ cứng động mạch
Nymphaea tetragona Georgi (phrase)

Transposition also occurs when nominalizations are translated as verbal forms in Vietnamese language since the Vietnamese tend to employ verbal structure (Tran 2004: 296) rathern than nominalizations as "detransitivizing devices" (Martínez, 2002, p. 1). Thus, in the following medical text, the nominalization "disease activity" is translated as the verbal construction "bệnh đang tiến triển" (disease being active) rather than "sự tiến triển của bệnh" (the activity of the disease):

\begin{tabular}{|l|l|}
\hline Source text & Translation \\
\hline $\begin{array}{l}\text { Fever accompanies a wide variety of illnesses and is a } \\
\text { valuable marker of disease activity. }\end{array}$ & $\begin{array}{l}\text { Sốt đi kèm với nhiều loại bệnh và là một chỉ dẫn có giá trị bệnh đang } \\
\text { tiến triển. }\end{array}$ \\
\hline
\end{tabular}

Transposition is also resorted to when the relationship among the lexical components of the term is seen from a different perspective in the target language. In the phrasal term "Acute drug induced tubuloinstertial nephritis", "nephritis" is modified by "tubuloinstertial", "drug induced", and "acute" in this sequence, so literal translation of the term will produce the target term "Viêm ống thận mô kẽ do thuốc cấp tính" (tubuloinstertial nephritis + drug induced + acute). However, in Vietnamese language, the cause is prone to pursue the characteristics of the disease, so this term is translated as "Viêm ống thận mô kẽ cấp tính do thuốc" (tubuloinstertial nephritis + acute + drug induced)

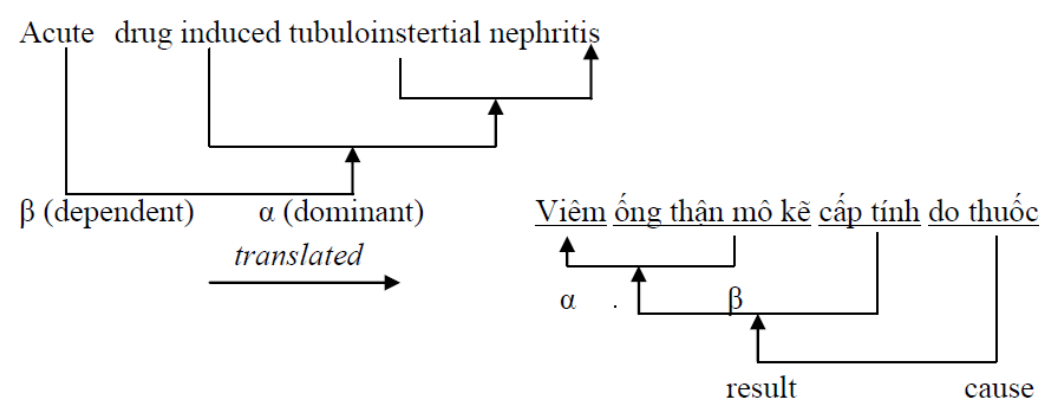

5) Modulation

Van Hoof (1989, p. 126) views "modulation as a type of transposition at the global level, applying to categories of thought, not grammatical categories".

Comparing the medical terms in Mosby's Medical Dictionary (6 $6^{\text {th }}$ ed.) (2002) with Vietnamese medical terms shows the reverse shifts of modulation forms found by Vinay \& Darbelnet (1977), Van Hoof (1989, p. 126), and Chuquet \& Paillard (1987, pp. 30, 26, 28), as well as different spatial viewpoint. Shifts in modulation are displayed in the following examples (Vietnamese translations trail the arrows).

(1) Abstract $\leftrightarrows$ concrete

Abstract $\rightarrow$ concrete:

$$
\begin{array}{ll}
\text { floating kidney } & \rightarrow \text { thận di động } \\
\text { (kidney }+ \text { moving) }
\end{array}
$$




$$
\text { frozen shoulder } \rightarrow \begin{aligned}
& \text { (rib }+ \text { cut off/too short) } \\
& \text { khớp vai hạn chế } \\
& \text { (shoulder + limited) }
\end{aligned}
$$

Concrete $\rightarrow$ abstract: $\quad$ sexually transmitted disease (STD)

$\rightarrow$ bệnh hoa liễu (disease + flower and willow [, which probably comes from the Japanese word karyūkai 花柳界 "the flower and willow world" implying the elegant, high-culture world of geisha]).

(2) Cause $\leftrightarrows$ effect

$$
\begin{aligned}
\text { Cause } & \rightarrow \text { effect: } \\
\text { Effect } \rightarrow \text { cause: } & \\
\text { (3) } \text { Means } & \leftrightarrows \text { result } \\
\text { Means } & \rightarrow \text { result: } \\
\text { Result } & \rightarrow \text { means: }
\end{aligned}
$$

(4) Part $\leftrightarrows$ whole

Part $\rightarrow$ whole:

Whole $\rightarrow$ part:

(5) $\mathrm{A} \leftrightarrows$ Negation of not-A

$$
\begin{aligned}
& \text { poliomyelitis } \quad \rightarrow \quad \text { Sốt bại liệt } \\
& \text { (fever + paralysis) } \\
& \text { tuberculosis } \rightarrow \quad \text { lao } \\
& (\text { tuber }=\text { swelling }) \quad(\text { due to working too hard }) \\
& \text { undescended testis } \rightarrow \quad \text { tinh hoàn ẩn } \\
& \text { (incomplete descending) (hidden testis) } \\
& \text { hemothorax } \rightarrow \text { tràn máu màng phổi } \\
& \text { (blood in the thorax) (blood flooding pleural cavity) } \\
& \text { ulna } \rightarrow \quad \text { xương trụ } \\
& \text { (ulna [Latin, elbow] = elbow bone) } \\
& \text { (xương trụ }=\text { the bone functioning as a pivot) }
\end{aligned}
$$

$\mathrm{A} \rightarrow$ Negation of not-A:

fainting $\rightarrow \quad$ bất tỉnh

$$
\text { (not }+ \text { conscious [= not fainting]) }
$$

Negation of not-A $\rightarrow$ A:

insanity $\rightarrow \quad$ loạn tâm thần (mental illness)

(in + sanity [= opposite "mental illness"])

(6) Different temporal/spatial viewpoint

Different temporal viewpoint:

prolonged pregnancy $\rightarrow$ thai già tháng

(too old fetus)

Different spatial viewpoint:

$\begin{aligned} & \text { meningococcemia } \rightarrow \\ & (\text { meninges = part) } \\ & \text { hydrothorax } \\ & \text { thorax = whole) } \\ & \text { sleepwalking } \\ & (\text { sleep = whole) }\end{aligned} \rightarrow \begin{aligned} & \text { nhiễm não mô cầu } \\ & \text { (the infection involving brain (= whole) tissue) } \\ & \text { tràn dịch màng phổi } \\ & \text { (fluid flooding pleural cavity (= part)) }\end{aligned}$
$\begin{aligned} & \text { mộng du } \\ & \text { (walking in the dream (= a part of the sleep)) }\end{aligned}$

(7) Different part/phase of the same process

articulatio radioulnaris distalis $\rightarrow$ khớp quay trụ dưới

$$
\text { (= inferior radioulnar joint) }
$$

Psoriasis [Greek, itch] is etymologically a minor symptom of the disease whereas its Vietnamese translation "vẩy nến" (wax-like scales) is a major manifestation of the disease.

(8) One metaphor to another

$\begin{array}{lll}\begin{array}{l}\text { heart murmur } \\ \text { risus sardonicus } \rightarrow\end{array} & \begin{array}{l}\text { âm thổi tim } \\ \text { (the blowing sound of the heart) } \\ \text { (laughter + mocking) } \\ \text { kneecap }\end{array} & \begin{array}{l}\text { vẻ mặt cười nhăn } \\ \text { (laughter + pulling faces) }\end{array} \\ \text { spur } & \rightarrow \quad \begin{array}{l}\text { xương bánh chè } \\ \text { (cake-shaped bone) }\end{array}\end{array}$

(spur $=$ spur-shaped projection of bone from a body structure $)$

(gai xương $=$ thorn-shaped projection of bone from a body structure)

tapeworm $\rightarrow$ sán xơ mít

(tape-shaped worm) (“jackfruit bulb” worm, implying worm resembling the edible bulbs of ripe jackfruit) roseola $\rightarrow \mathrm{b}$ an đào (Luu, 2009)

(= rose-colored rash) ("peach blossom" rash, implying peach blossom-colored rash)

(9) Metaphor $\leftrightarrows$ Non-metaphor

Metaphor $\rightarrow$ Non-metaphor: cradle cap $\rightarrow$ bệnh nấm da đầu 
Non-metaphor $\rightarrow$ Metaphor: lymphogranuloma venereum (LGV)

(dermatitis of the scalp)

$\rightarrow$ bệnh hột xoài

("mango stone" disease, in which the metaphor "mango stone" refers to marked swelling of the lymph nodes in the groin)

epidemic parotitis $\quad \rightarrow \quad$ bệnh quai bị

("bag-shaped swollen jaw" disease)

(10) Popular style $\leftrightarrows$ Professional/Academic style

Popular style $\rightarrow$ Professional/Academic style:

windpipe $\rightarrow \quad$ khí quản (equivalent to "trachea" in terms of stylistic scale)

Professional/Academic style $\rightarrow$ Popular style:
anaemia $\quad \rightarrow \quad$ thiếu máu ("lack of blood")
ductus arteriosus $\rightarrow \quad$ ống động mạch ("arterial duct")
molluscum $\rightarrow \quad$ u mềm ("soft tumor")
in vivo $\quad \rightarrow \quad$ trên cơ thể sống ("on the human body")

(11) One color to another

pinkeye $\quad \rightarrow \quad$ bệnh đau mắt đỏ ("red eye")

cyanosis $\quad \rightarrow \quad$ chứng xanh tím

[Greek, kyanos, blue] ("blue and violet skin")

6) Adaptation

Adaptation is "the search for the term's equivalent in the target language based on its set of semantic component as a whole, rather than translating each semantic or lexical component of the term" (Luu, 2011).

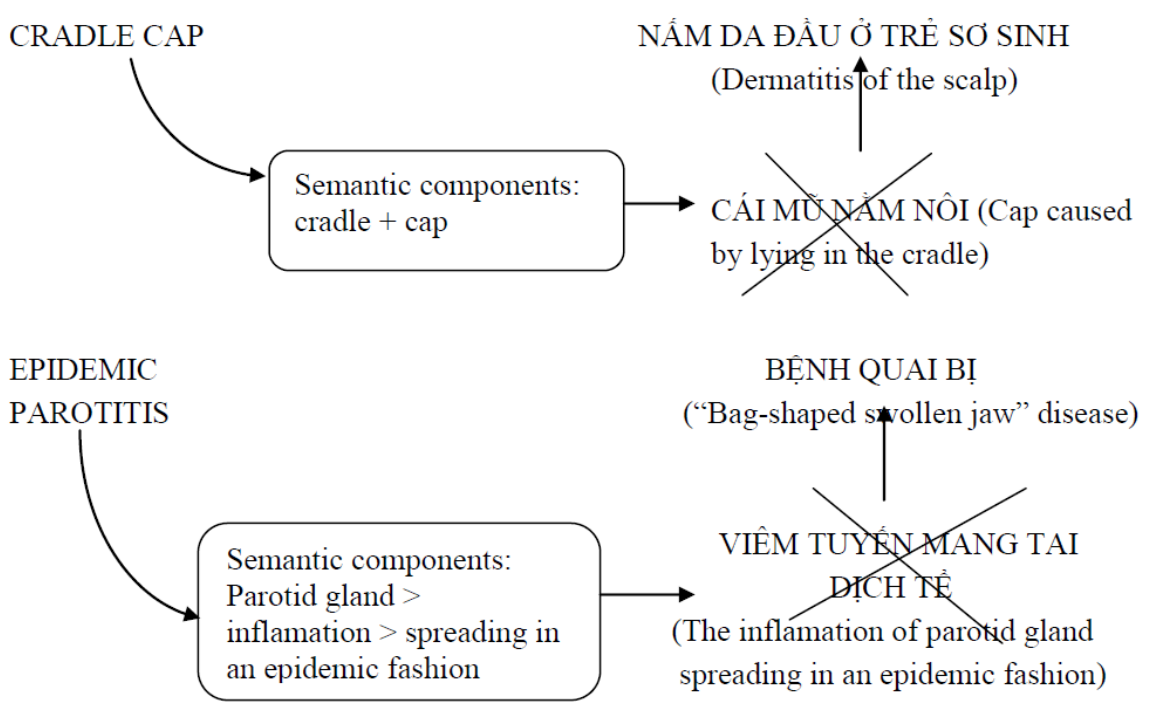

\section{TRanslating Terms in the ConteXt}

Luu (2011) proposes Coordinate Translation Model "which has three axes: $\mathrm{X}$ axis - translation unit axis, Y axis concept equivalent axis, and $\mathrm{Z}$ axis - language task schema axis" as displayed in Figure 2. 


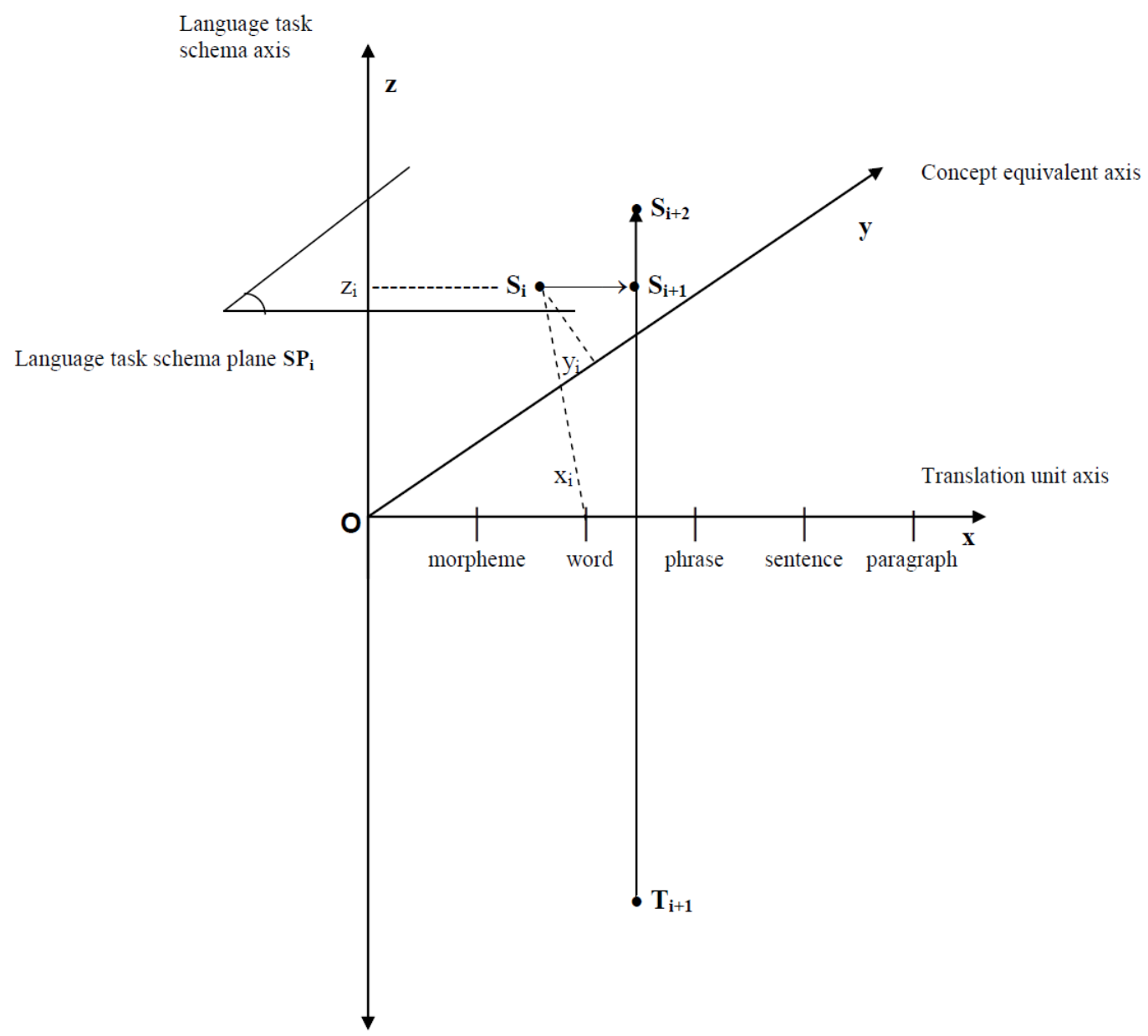

Figure 2. Coordinate translation model

For instance, facing the phrase "yellow fever" in the text at http://www.who.int/mediacentre/factsheets/fs100/en/, the translator needs to determine if the translation unit(s) is (are) the whole phrase "yellow phrase" or words "yellow" and "fever". In view of the semantic components of "yellow" [color > yellow] and "fever" [body temperature > exceeding $37^{\circ} \mathrm{C}$ ], "yellow" can not be an adjective of the noun "fever", so the translation unit is the entire phrase "yellow fever". This translation unit is further confirmed through the analysis of the interaction between the phrase and the intrasentential/inter-sentential components. In the first sentence, the complement "a viral disease" provides a definition for the subject "yellow fever", asserting that "yellow fever" is not a symptom (if "yellow fever" were an unidiomatic phrase, it would be a symptom), but a disease. Furthermore, the fourth sentence shows that the component "yellow" is not an attribute of "fever", but a symptom. Thus, "yellow fever" is composed of two major symptoms "yellow" and "fever", and here there is a transition from $\mathrm{x}_{\mathrm{i}} \rightarrow \mathrm{x}_{\mathrm{i}+1}=$ word $\rightarrow$ phrase, and the term "yellow fever" is translated as "sốt vàng da" (fever + jaundice), not "sốt vàng" (fever + yellow) in Vietnamese language.

Unlike the above case, the text at http://www.fpnotebook.com/ID45.htm provides an illustration on words being discerned as translation units. In the text, the phrases "remittent fever", "intermittent fever", "hectic fever" and "sustained fever" can be decomposed into words as translation units since the lexical components "remittent", "intermittent", "hectic" and "sustained" represent the attributes of the concept "fever". Governed by the text title "Fever", these phrases display the types of fever defined at B.1\&2, C.1\&2, D.1\&2, và E.1\&2, and are translated as "tái hồi", "từng cơn", "thất thường" and "liên tục". On the contrary, at C.3.b. in the text, the term "relapsing fever" is an example of the diseases with Intermittent Fever, so cannot be broken down into two translation units "relapsing" and "fever".

\section{CONCLUSION}

Scientific terms contribute to academic style of a science text. Translating a scientific term, whether inside or outside a context, involves identification of translation units, functional equivalence degree, and how semantic components are recombined. The paper also revisits Vinay \& Darbelnet's (1977) translation procedures for translating terms outside the context, as well as proposes Coordinate Translation Model for translating terms in the context. 


\section{REFERENCES}

[1] Anderson, D.M., Keith, J., Novak, P.D., \& Elliot, M.A. (2002). Mosby's Medical Dictionary (6 ${ }^{\text {th }}$ ed.). Missouri: Mosby, Inc.

[2] Arntz, R, \& Picht, H. (1991). Einführung in die Terminologiearbeit. Hildesheim: Olms.

[3] Cao, V.D. (2005). Suy nghĩ về dịch thuật và ngôn ngữ văn chương (Thoughts on Translation and LiteraryLanguage). Retrieved on July 92008 from http://vietnamnet.vn/vanhoa/chuyende/2005/12/526939/

[4] Chuquet, H. \& Paillard, M. (1987). Approche Linguistique des Problème de Traduction. Gap: Ophrys.

[5] Ebbing, D.D., Wentworth, R.A.D., and Birk, J.P. (1995). Introductory Chemistry. Boston, MA: Houghton Mifflin Company.

[6] Fromkin, V. (Ed.) (2000). Linguistics: An Introduction to Linguistic Theory. Oxford: Blackwell Publishers.

[7] Green, D.W. (1998a). Mental control of the bilingual lexico-semantic system. Bilingualism, No. 1, pp. 67-81.

[8] Green, D.W. (1998b). Schemas, tags and inhibition. Reply to commentators. Bilingualism, No. 1, pp. 100-4.

[9] Jakobson, R. (1959). Linguistic aspects of translation. In Brower (Ed.), On Translation. Cambridge, Mass.: Harvard University Press.

[10] Lam, P.T. (2003). Từ điển y học Anh-Anh-Việt (English-English-Vietnamese Medical Dictionary). Ho Chi Minh City: Medical Publishing House.

[11] Le, V.T. (1984). Hội chứng và bệnh học thần kinh (Syndromes and Pathology of Neurology). Ho Chi Minh City: Medical Publishing House.

[12] Luu, T.T. (2009). Building Vietnamese Medical Terminology via Language Contact. Australian Journal of Linguistics, 29(3), $315-336$

[13] Luu, T.T. (2011). Strategies to Translate Information Technology (IT) Terms. Theory and Practice in Language Studies, 1(1), $1-7$.

[14] Martínez, M.A. (2002). The foregrounding function of nominalizations in narrative discourse: a case study of Pynchon's "Under the Rose" and V. chapter 3. Manuscript.

[15] Mengzhi, F. (1999). Sci-tech translation and its research in China. Meta: Journal des traducteursMeta:/Translators' Journal, 44(1), 185-197.

[16] Newmark, P. (1995). A Textbook of Translation. London: Prentice Hall Europe.

[17] Ohly, R. (1987). Primary Technical Dictionary. Institute of Production Innovation, Dar-es-saalam and Deustche Gesellschaft fu $\mathrm{r}$ Technische Zusammernarbeit, Eschborn.

[18] Tran, N.T. (2004). Tìm về bản sắc văn hóa Việt Nam: Cái nhìn hệ thống - loại hình (Discovering the Identity of Vietnamese Culture: Typological-Systematic Views). Ho Chi Minh City: General Publishing House.

[19] Van Hoof, H. (1989). Traduire l'Anglais. Paris \& Louvain-la-neuve: Duculot.

[20] Vinay, J.P., \& Darbelnet, J. (1977). Stylistique Comparée du Français et de L'Anglais. Paris: Didier.

[21] Zhu, C. (1999). Ut once more: The sentence as the key functional unit of translation. Meta: Translators' Journal, Vol. 44, No. 3, p. $429-447$.

Luu Hoang Mai is an EFL lecturer at Thu Dau Mot University, Binh Duong Province, Vietnam. She earned her MA in TESOL from Victoria University, Australia. Her research interest includes linguistics, translation, and English teaching.

Luu Thi Bich Ngoc earned BA degree from National University of Ho Chi Minh City. She is now a teacher at Open University, Ho Chi Minh City, Vietnam and displays research interests in classroom management and educational leadership.

Luu Trong Tuan is currently a lecturer in reasearch methodology at Open University, Ho Chi Minh City, Vietnam. He received his PhD from Asian Institute of Technology, Thailand. 